\title{
Supraglottic Cancer pMX TNM Finding v6
}

National Cancer Institute

\section{Source}

National Cancer Institute. Supraglottic Cancer PMX TNM Finding v6. NCI Thesaurus.

Code C64743.

Suprag lottic cancer in which distant metastasis cannot be assessed. (from AJCC 6th Ed.) 